\title{
A felső tagozatos és a középiskolai biológia tankönyvek szerepe az egészségnevelésben
}

\author{
The role of elementary school senior class- and secondary school \\ biology textbooks in health education
}

Szerzők: Szalainé Tóth Tündea $\quad$ Nagyné Horváth Emíliab ${ }^{b}$ Falus Andrásc $₫$, Bihariné Krekó Ilona ${ }^{d}$,

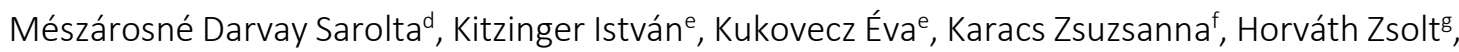
Kőrösiné Molnár Andreag, Jánossyné Solt Annah, Feith Helga Juditi

a: Lovassy László Gimnázium, Veszprém, b: Kőbányai Bem József Általános Iskola, Budapest,

c: Semmelweis Egyetem, Általános Orvosi Kar, Genetikai, Sejt- és Immunbiológiai Intézet, d: Eötvös Loránd Egyetem, Tanító és Óvóképző Kar, Természettudományi Tanszék, e: Vörösmarty Mihály Gimnázium, Érd, f: Tamási Áron Általános Iskola és Német Két Tannyelvü Nemzetiségi Gimnázium, Budapest, g: Gödöllöi Református Líceum Gimnázium, h:Városmajori Gimnázium, Budapest, i: Semmelweis Egyetem, Egészségtudományi Kar, Társadalomtudományi Tanszék

Beküldve: 2019. 01.28.

doi: $\quad$ 10.24365/ef.v60i2.413

„Határozottan hiszek abban, hogy értékitéletünk koordinátái már egészen korán kialakulnak. Mindaz, amit később teszünk, ezen az értékrenden alapul."

(Szent-Györgyi Albert)

A szerzőkről:

Szalainé Tóth Tünde: biológia-kémia szakos középiskolai tanár Nagyné Horváth Emília: biológia-kémia szakos általános iskolai tanár Falus András: professzor emeritus, a TANTUdSZ program vezetője Kitzinger István: biológia-környezettan szakos középiskolai tanár Kukovecz Éva: földrajz-biológia szakos középiskolai tanár Bihariné Krekó Ilona: címzetes egyetemi docens Mészárosné Darvai Sarolta: habilitált egyetemi docens Horváth Zsolt: biológia-kémia szakos középiskolai tanár Kőrösiné Molnár Andrea: biológia-földrajz szakos középiskolai tanár Karacs Zsuzsanna: biológia-kémia szakos középiskolai tanár Jánossyné Solt Anna: biológia-kémia szakos középiskolai tanár Feith Helga Judit: főiskolai tanár 
Összefoglaló: Az ifjúsági egészségfejlesztés nagy jelentőségű a jelen és a jövő társadalma számára. Mindehhez az iskolai tananyagokon túl komplex, átfogó és a gyakorlati munkában, tanácsadásban is jól használható, felelősségteljes információkat kívánunk adni a korszerú környezettudatosság, a táplálkozás, a mozgáskultúra és a szenvedélybetegségek kérdésein át többek között az iskola-egészségügy, a mentálhigiéné, a pszichoszomatikus kórképek, az egészséges öregedés, a család és a bioetika legfőbb kérdéseinek köréből. Ehhez pontos ismeretek szükségesek az iskolai tananyag egészségneveléssel kapcsolatos részleteit illetően. Áttekintésünk alapján megállapítható, hogy az ötödik osztálytól a nyolcadikig, majd tizenkettedikig a természettudományos tanulmányi-oktatási terv és az oktatási tananyag (egy-két részletkérdéstől eltekintve) alkalmas az egészségtudatosságra való nevelés korcsoportra specifikus alapjainak lerakására.

Kulcsszavak: egészségnevelés; köznevelés; biológia oktatás; tankönyvek

Summary: Youth health promotion is of great importance for present and future society. For this, beyond school curricula, we want to provide comprehensive, complex, and reliable information well-developed for use in practice and counselling, including the issues of modern environmental awareness, nutrition, movement culture and addictions, among others, the key issues of school health, mental health, psychosomatic diseases, healthy aging, family and bioethics. This requires accurate knowledge of the school curriculum related to health education. Based on our review it can be concluded that from the fifth grade to the eighth, and then to the twelfth, the science education plan and educational curriculum (apart from one or two minor details) are suitable for laying the foundation for the age-specific basis of health awareness education.

Keywords: health education; public education; biology teaching; textbooks

\section{BEVEZETÉS}

Nem vitatható, hogy a családi és az óvodai hatások mellett a tudatos egészségnevelés legfontosabb színtere az iskola, amit a fiatal korosztály hosszú éveken át látogat. Ha a fiatalok jó példát látnak maguk körül és a diákok megismerik azokat a lehetőségeket, hogy miként lehet bizonyos betegségeket elkerülni, miért fontos az egészséges életmód, akkor a gyermekek nagyobb eséllyel válhatnak egészséges felnőttekké. ${ }^{1} \mathrm{Az}$ iskola olyan keretet adhat, melynek segítségével mód nyilik az egészségesebb életvitel készségeinek, magatartásmintáinak kialakítására és gyakorlására.

Az egészségnevelés a mai Nemzeti Alaptanterv (NAT) közös követelményeiben és szándékaiban áthatja az iskolai élet valamennyi színterét. Kiemelt feladat, hogy az iskola minden tevékenységével szolgálja a tanulók egészséges testi, lelki és szociális fejlődését. Az egészséges, egészségtudatos életmódra nevelés nemcsak a betegségek megelőzésének módjára tanít, hanem az egészség örömteli megélésére és a harmonikus élet értékként való tiszteletére is nevel. Az iskolák fontos feladata, hogy fejlesszék a beteg, sérült és fogyatékossággal élő embertársak iránti elfogadó és segítőkész magatartást. Ismertessék meg a környezet leggyakoribb, egészséget, testi épséget veszélyeztető tényezőit. Nyújtsanak támogatást a gyerekeknek - különösen a serdülőknek - a káros függőségekhez vezető szokások (pl. dohányzás, alkoholés drogfogyasztás, egészségtelen táplálkozás, internetfüggőség) kialakulásának megelőzésében. Segítsék a krízishelyzetbe jutottakat. Az iskola megkerülhetetlen feladata, hogy foglalkozzon a szexuális kultúra és magatartás kérdéseivel, és figyelmet fordítson a családi életre nevelésre. ${ }^{2}$ Mindezen fejlesztési feladatok megvalósításához szükséges, hogy a pedagógusok minden segítséget megkapjanak. A Magyar Tudományos Akadémia által támogatott Tanulj, Tanítsd, Tudd! (TANTUdSZ) nevű tantárgy-pedagógiai-, kortársoktatáson alapuló program egyik célja pontosan az, hogy felhívja 
az érintett pedagóguskollégák figyelmét az egészségtudatossági tartalmak fontosságára és segítse felhasználásukat. ${ }^{3}$

A fizikai és a mentális egészségnevelés módszertana szerteágazó, és ebben megkérdőjelezhetetlen a tankönyvek fontos szerepe. Az egészségnevelés alapvető célja, hogy 1) a tanulók korszerú ismeretekkel, és azok gyakorlásához szükséges képességekkel, jártasságokkal rendelkezzenek az egészségük védelme érdekében s 2) az, hogy motiválja a tanulókat: bővítsék az egészségre vonatkozó fogalomkészletüket. Ehhez szükség van korszerü, nemcsak jól kézbevehető, de digitálisan is elérhető tankönyvekre, melyek segítik a tanár munkáját és felkeltik a tanulók érdeklődését a téma iránt.

Az általános iskolák felső tagozatában és a középiskolákban ma a Z generáció - az 1995 után születettek - tagjait tanítjuk. Csak akkor érünk el eredményt az egészségfejlesztés terén, ha kellőképpen motiváljuk diákjainkat, életközelivé tesszük a tananyag feldolgozását, felhasználjuk a felnövő korosztály által preferált új digitális technológiai eszközöket. Kiemelt fontosságú a pedagógus személyes példamutatása, valamint a kortársak szerepe. Azonban mindezek mellett szükség van jó tankönyvekre is! Olyanokra, amelyek ábra- és ismeretanyagukkal felkeltik a tanulók érdeklődését, amelyek szakmailag hitelesen és olvasmányosan biztosítják az egészségügyi alapismertek elsajátítását. A tankönyv legyen ismeretterjesztő, tartalmazzon tudománytörténeti áttekintést, a diák pedig találjon benne sok-sok gyakorlati tudnivalót! Találjon választ a mindennapi életben felmerülő kérdésekre. Hívja fel a figyelmet a tankönyv a vizsgálódásokra, az egyéni ismeretszerzésre, kutatómunkára.

Áttekintésünk során találkoztunk olyan jó tankönyvekkel, amelyeket hatékonyan használhatunk a biológiaórákon az egészségtudatos életmódra nevelés kapcsán. Ehhez azonban minden esetben szükség van a pedagógusok módszertani sokszínúségére, $s$ az egészségfejlesztés, tudatos egészségnevelés iránti elhivatottságára. Az ifjúság egészségnevelése kiemelkedő fontosságú a jelen és jövő társadalma számára. Bízunk abban, hogy a készülődő új NAT-ban is kellő hangsúlyt kap az egészségnevelés, $s$ a jövő iskolájában olyan könyveket és digitális segédleteket kapnak majd kézbe a fiatalok, amelyek révén hatékony egészségnevelésben részesülnek.

Jelen cikkünkben a felső tagozatos és a középiskolai biológia tankönyveket tekintjük át arra fókuszálva, hogyan jelenik meg bennük az egészségtudatosságra nevelés és az egészségfejlesztés.

\section{Felső tagozatos biológia tankönyvek}

\section{Természetismeret az 5-6. osztályban}

Az elemzett tankönyvek szerzői témakörönként sokoldalú lehetőséget nyújtanak az egészségnevelésre: egészséges táplálkozás, kártevők elleni védekezés, madáretetés, haszonállatok fontossága, az állattartás felelőssége, hogy csak néhányat említsünk. ${ }^{4}$ Ezek csupán lehetőségek, amit a tanár kihasználhat.

A hatodik osztályosok tankönyve az erdő életközössége és a vizek, vízpartok élóvilága témakörökön kívül tartalmazza az ember szervezettani felépítését és működését, valamint egészségmegőrzés, családi kapcsolatok, energia, Föld és a világegyetem, éghajlat, Magyarország témákat is. $\mathrm{Az}$ életközösségek témakörben hangsúlyt helyez az élőlény és a környezet kapcsolatára.

Lényeges, hogy a tananyag mindegyik szervrendszer múködésénél említ egészségügyi problémákat is, kivéve a szív- és érrendszeri betegségeket, amiről nem egészen érthető módon - nem szól. A nemek közti különbségek és a családi kapcsolatok témánál a testi és lelki, illetve a családi higiénia kap szerepet. Az egészségmegőrzésnél szóba kerülnek a fertőzést kiváltó tényezők, baktériumok, vírusok (pl. az AIDS okozója a humán immunhiány vírus, azaz a HIV), emellett az alkohol, a dohányzás, a kábítószerek, a nyugtatószerek, a stressz és a különleges fontosságú elsősegélynyújtás. A tankönyvi ábrák demonstrációs hatékonysága igen jó, talán több ábra még jobban megszólítaná ezt a korosztályt. ${ }^{5}$ 
Biológia, illetve biológia-egészségtan a

7-8. osztályban

Az elemzett tankönyvek szerzői minden témakörben (idegen tájak életközösségei, élőlények rendszerezése, környezeti hatások) felhívják a figyelmet a természet-környezet védelmére, a nemzeti parkok esetében a természetjárásra. Ez a tananyag a globális problémákat és azok hatásait is elemzi (klímaváltozás, esőerdők kiirtása, energia- és hulladékprobléma). A gyógynövényeket a termesztett növényeknél említik, ugyanakkor kár, hogy a rendszertani csoportoknál nincs utalás bizonyos növények gyógyhatásaira. A kórokozó vírusok említésre kerülnek, de a betegséget nem okozó baktériumok (mikrobiom) egészségünket nagymértékben befolyásoló hatása nem. A képek motiválóak és jó feladatok, elemzések közül lehet választani. ${ }^{6}$

A nyolcadikos biológia tankönyvek anyaga felöleli az ember szervezettani felépítését és múködését. Mindegyik szervrendszer múködésénél tárgyalja az egészségügyi problémákat is. Az életkori sajátosságoknak megfelelően a tankönyv kitér az elhízás, fogyókúra problémájára is. ${ }^{7}$

A közlés stílusa a korosztálynak megfelelő, ugyanígy a témák mélysége és a tananyag magyarázata is. A tankönyvben megfelelő módon bevezetett gyakorlati órák, gondolkodtató feladatok, érdekességek, a mindennapokból vett példák olvashatóak és jól használható projektmunkákat is talál a pedagógus. Az anyagot kiegészíti a részletes, korrekt kislexikon tényanyaga is.

Az Oktatáskutató és Fejlesztő Intézet (OFI) kiadásában készült nyolcadikos biológiaegészségtan kísérleti tankönyv esetében minden összefoglalásnál vannak használható projektfeladatok. Ezek és a motiváló rajzok, valamint az egyéb feladatok jó alapot adnak a gyermekegészségügyi alapismeretek és a higiéniai téma gyakoroltatásához. Az utolsó fejezetben tárgyalt „Felelősségünk önmagunkért, egymásért, a Földért” témához jól illeszthető a lelki egészség komplex problematikája és a környezeti tényezők szerepe is. ${ }^{8}$

\section{Középiskolai biológia tankönyvek}

Az alábbi tankönyvek közül a hivatalos Köznevelési Tankönyvjegyzékben csak a Lénárd- és a MándicsMolnár-féle tankönyvcsaládok kötetei szerepelnek, de egyéb tankönyvekhez is hozzá lehet még jutni. Több iskola, szaktanár ragaszkodik ez utóbbi, régebben megjelent, kipróbált és jól bevált tankönyvekhez.

\section{A Lénárd-sorozat}

A jelenlegi Lénárd-sorozat a régi, jól ismert három kötetes tankönyvek újragondolása, átdolgozása. A változtatásban figyelembe vették a szerzők a megváltozott kimeneti követelményeket, azaz az új részletes érettségi vizsgakövetelményeket.

A tankönyvek tartalma, ábraanyaga jól kapcsolható a mindennapi élethez. Természetesen az embertan témakörében szerepel a legtöbb kapcsolat az egészségre neveléssel. Minden szervrendszer esetében számos megbetegedést ismertet. A könyvekben szervrendszerenként sok példát találunk egészségi kockázatra, megelőzésre. Részletesen foglalkozik a szaporodás és egyedfejlődés témakörnél a fogamzásgátlási lehetőségekkel, valamint a szexuális úton terjedő betegségekkel. A rendszertan és az ökológia témákban is megjelenik kisebb-nagyobb mértékben az egészség- és környezettudatosság.

Ha azt nézzük, hogy mi található az érettségi követelményrendszerben, ennek elvárásait a Lénárdsorozat teljesíti. Az egészség és a valódi környezettudatosság területén felmerülő hiányosságok is éppen ennek tulajdoníthatóak, hiszen a szerzők a kimeneti követelményeknek megfelelően készítették el a vizsgált tankönyveket. Viszont - mivel az „egészség mindenkié" - a biológia tananyagban kellene minél több lehetőséget biztosítani az egészségneveléshez, hiszen nem mindenki fog érettségizni, de a tankönyvek egészségnevelési részei a nem érettségizőknek is kell, hogy szóljanak. 9,10,11 


\section{A „Biológia-egészségtan" tankönyvek}

A Mándics és Molnár által írt biológiakönyvek címe a NAT kerettanterveknek megfelelően: Biológiaegészségtan. S a címhez hűen számos helyen találunk egészségtani hivatkozásokat a könyvekben. A 10. osztályosoknak íródott kiadvány főbb témakörei: rendszertan, etológia, valamint kisebb terjedelemben megjelenő ökológia és evolúció. Ezek a témák is lehetőséget adnak az egészségnevelésre és arra is, hogy környezettudatosságra neveljük a diákokat. Többek között a baktériumokról, vírusokról, gombákról, férgekről, ízeltlábúakról és az emlősökről tanítva kapcsolódhatunk a könyv ismeretanyagára támaszkodva a mindennapi élethez. Ezekben a témákban előkerülnek a különféle kórokozók által okozott betegségek, a gombamérgezések, mindezek elkerülésének lehetőségei, valamint a testi higiénia alapszabályai.

A növénytanban kevés szó esik a növények emberi táplálkozásban betöltött szerepéről, illetve a gyógynövényekről. Az ökológia témakör nagy hangsúlyt fektet arra, hogy tudatosítsa: az ember része a természetnek. A feldolgozás során viszont rávilágíthatunk arra is, hogy az ember a természetátalakító tevékenységével olyan károkat okozhat, ami visszahat a bioszféra élőlényeire, így az emberre is. A tankönyvben számos érdekes olvasmány teszi életközelivé a tananyagot, de természetesen szükség van arra, hogy a tanárok a tankönyvi anyagon túl, minél több módon motiválják a diákokat, illetve minél több lehetőséget találjanak arra, hogy kapcsolatba hozzák a tanultakat a mindennapi élettel. ${ }^{12}$

A 11. osztályosoknak szánt kötet ismeretanyaga teljes mértékben illeszkedik a tankönyv címéhez. A sok-sok olvasmány, a kísérletezésre, vizsgálódásra való lehetőség, a leckevégi kérdések, feladatok segítik az interaktív feldolgozást, a mindennapi élethez való kapcsolódást, így felkeltik a diákok érdeklődését $\mathrm{s}$ az igényét az egészségtudatos életre. Az emberi szervrendszerek tanítása során lehetőség nyílik arra, hogy bővítsük a diákok egészségügyi alapismereteit. Átfogó képet kaphatnak a káros szenvedélyek egészségkárosító hatásairól, a civilizációs betegségekről, valamint a felelős, tudatos utódvállalás, a családi élet és környezet fontosságáról is. A tankönyv arra is alkalmas, hogy rávilágítson: a betegségek kialakulásában az örökletes tényezők mellett az életmódnak, az epigenetikai tényezőknek is fontos szerepe van. ${ }^{13}$

A tizenkettedikes kötet legtöbb témaköre a mindennapi élethez illeszkedően foglalkozik az egészségneveléssel, hiszen a "Genetika”, a "Modern genetika a mindennapokban”, az "Ember egyéni és társas viselkedése", valamint a "Gazdálkodás és fenntarthatóság" témakörök tartalmaznak napi aktualitásokat is. Mindezek még jobban felkeltik a tanulók figyelmét és érdeklődését. A leckék tárgyalási módja, az érdekes olvasmányok, a kísérletek, vizsgálódások, az egyéni kutatómunkára felszólító lehetőségek ugyancsak fokozzák az igényt az egészségtudatos életmódra. A tananyag megismerése során képet kapnak a diákok a genetikai betegségekről, az epigenetikai tényezők szerepének fontosságáról, a modern genetikai eljárások etikai és jogi vonatkozásairól, a testképzavarok (kóros elhízás és kóros soványság) okairól, következményeiről, a környezetszennyezés és az ember természetátalakító tevékenységének következményiről. Ezek a tankönyvi megoldások mind hozzásegítik a nagykorúság küszöbén álló fiatalokat, hogy egészség- és környezettudatos felnőttekké váljanak. ${ }^{14}$

\section{A mozaikos tankönyvek}

A Mozaik Kiadó által jegyzett tankönyvek nagyon népszerűek az emelt szintű érettségire történő felkészítésben. ${ }^{15,16,17}$ Gál tankönyvei közül a 11. osztályosoknak íródott kötet címe: a Sejt és az ember biológiája. Az embertan témakörben szerepelnek az egészségtani alapismeretek, az elsősegélynyújtás, a védőoltások, az egyes betegségek kialakulásának okai, ezek kezelésének, gyógyításának lehetőségei. ${ }^{16}$ Környezettani vonatkozások és tudománytörténeti utalások is helyet kaptak a szerző köteteiben. ${ }^{15,16,17}$ A Szerényi által írt Biológia érettségizőknek 1 . és 2 . tankönyvek a részletes érettségi vizsgakövetelmény alapján az emelt szintű érettségizőknek íródtak. Céljuk a sikeres emelt szintű érettségire történő felkészítés, így az egészségtani ismeretek átadásán kívül további célként nem jelenik meg a motiválás és az érettségi témakörén túlmutató ismeretterjesztés. ${ }^{18,19}$ 


\section{Az Oláh-féle tankönyvek}

Az Oláh által fémjelzett biológia tankönyvcsalád 3 kötetben, a biológiaoktatás évfolyamos tagolásának megfelelően dolgozza fel a középiskolás biológiai ismeretanyagot: a Biológia 10. kötet elsősorban az élőlények rendszerezéséről, életmúködéseikről szól. Ennek során, különösen az emberről szerzett információk hiányában csak nagyon érintőlegesen találhatók az egészségneveléssel kapcsolatos ismeretek. ${ }^{20} \mathrm{~A}$ Biológia 11 . kötet a sejtek anyagcsere-folyamatairól, valamint az embertanról szól, főleg itt találhatóak egészségtani alapismeretek. ${ }^{21}$ A Biológia 12. kötet első fele a genetika törvényszerűségeivel, míg második része az evolúció és az ökológia témakörével foglalkozik. ${ }^{22}$ A tankönyvekben alapvetően megfigyelhető az egészségvédelmi ismeretek széles körű, a mindennapi életre vonatkozó átadása.

\section{A Zátonyi-féle tankönyvek}

Az Apáczai Kiadó által egykoron megjelentetett Zátonyi: Biológia a gimnáziumok 11. évfolyama számára nevű tankönyv anyaga átfogóan, jól szemléltetve írja le az emberi szervrendszerek felépítését és múködését. Mindegyik szervrendszer esetében részletesen bemutatja az ahhoz kapcsolódó egészségügyi problémákat. Nagyon hasznos, hogy nemcsak a "közismert” problémákat ( $p l$. hasmenés, tüdőgyulladás, csonttörés) tárgyalja, hanem a gyerekek számára nehezebben elmagyarázható, manapság gyakran előforduló jelenségekkel (pl. anorexia, Lyme-kór, testékszerek, nemi úton terjedő fertőző betegségek, AIDS) is kimerítően foglalkozik. Kiemelendő, hogy külön fejezeteket szán az egészségügyi ismeretekhez kapcsolódó nagyon lényeges kérdésekre: pl. a tisztálkodás szabályaira, a haj, a bőr és az élelmiszerek higiéniájára. Összefoglalja a daganatos betegségek megjelenéséért felelős környezeti tényezőket, életmódbeli faktorokat, genetikai okokat és lelki tényezőket. Tárgyalja a testedzés hatását a szervezet egészére, az edzés típusait, azok speciális hatásait. Bemutatja az elsősegélynyújtás alaplépéseit. A szenvedélybetegségek közül kiemelten, részletesen tárgyalja a dohányzást, az alkoholizmust, a különböző kábítószereket, rövidebben ír a koffeinről és megemlíti a viselkedési függőségeket. A témakörökhöz kapcsolódnak a gyerekek figyelmét felkeltő kérdések, feladatok. A könyv nagyon jó alapot ad a gyermekek egészségügyi és higiéniával kapcsolatos alapismereteinek elmélyítéséhez. ${ }^{23}$

\section{Szakgimnáziumok - tankönyv nélkül}

A szakgimnáziumok 9. osztályában heti 3 órában komplex természettudomány tantárgyat tanulnak a diákok, ehhez azonban sajnálatosan nincs hivatalosan forgalomban lévő tankönyv. Így az itt tanító pedagógus óriási felelőssége az, hogy átadja a tanulóknak azokat az egészségtani alapismereteket, amelyek nélkülözhetetlenek ahhoz, hogy egészségtudatos felnőttekké váljanak a szakgimnazista fiatalok is. Az Eszterházy Károly Egyetem (a volt OFI) munkatársai által a Nemzeti Köznevelési Portálon ${ }^{24}$ készített oktatási segédanyagok értékes segítséget nyújtanak ebben. Ezeket az anyagokat minden iskolatípusban tanító szaktanárnak is ajánljuk.

\section{ÖSSZEGZÉS}

A biológiaoktatásban használt tankönyvek alkalmasak a diákok egészségtudatos szemléletének alakítására. Az általunk elemzett tankönyvek összességében jól szolgálják az egészségnevelést, különösen, ha motiváló, interaktív módszerekkel történik a bennük lévő ismeretek átadása. Az egészségformálás ezekkel a kiadványokkal - természetesen tanári segítséggel, irányítással - megvalósulhat a tizenéves korosztályban. Mint ismeretes, az egészség dimenziói a testi, lelki, mentális, emocionális és a szociális egészség. A diákok a tananyag jellegéből adódóan elsősorban a testi egészség terén találnak felvilágosítást, egészségügyi alapismereteket tankönyveikben. Az ember magatartását és a szaporodást feldolgozó témakörökben előkerül a lelki és mentális egészség is. Fontos, hogy különösen a prevenciót hangsúlyozva kerüljön sor a betegségek megbeszélésére. Amit a legkevésbé érintenek az elemzett tankönyvek: az emocionális, illetve a szociális egészség. Ezek azonban előkerülnek a tankönyvek, a tananyagok feldolgozása során - pl. a csoportmunkák kiválóan alkalmasak a szociális kompetenciák fejlesztésére, így a szociális egészség formálására, továbbá a környezeti hatások bemutatására a tudatos életmódra nevelésben. 


\section{HIVATKOZÁSOK}

${ }^{1}$ Feith HJ, Lukács Á, Gradvohl E, et al. Health education - responsibility - changing attitude. Acta Univ. Sapientiae, Social Analysis. 2018;8:55-74. doi: 10.2478/aussoc-2018-0004

${ }^{2}$ Darvay S. Intézmények közötti együttmüködés az iskolai egészségfejlesztés megvalósitásában. Iskolások Egészségéért XII. Országos Továbbképző Konferencia. Fodor József Iskolaegészségügyi Társaság, Budapest, 2016. október 14.

${ }^{3}$ Lukács JÁ, Mészárosné Darvay S, Soósné Kiss Zs és mtsai. Kortárs egészségfejlesztési programok gyermekek és fiatalok körében a hazai és a nemzetközi szakirodalom tükrében - Szisztematikus áttekintés. Egészségfejlesztés. 2018;59:6-25. doi: 10.24365/ef.v59i1.215

${ }^{4}$ Csákány A, Hartdégenné Rieder É, Rugli I. Természetismeret 5. Nemzedékek Tudása Tankönyvkiadó, Budapest, 2013.

${ }^{5}$ Csákány A, Dombórávi L, Hartdégenné Rieder É. Természetismeret 6. Nemzedékek Tudása Tankönyvkiadó, Budapest, 2013.

${ }^{6}$ Asztalos Gy, Paál T. Biológia 7. Nemzedékek Tudása Tankönyvkiadó, Budapest, 2016.

7 Kovács I, Victor A, Paál T. Biológia 8. Nemzedékek Tudása Tankönyvkiadó, Budapest, 2016.

8 Kropog E. Biológia-egészségtan 8. Oktatáskutató és Fejlesztő Intézet, Budapest, 2016.

${ }^{9}$ Lénárd G. Biológia a gimnáziumok számára 10. Oktatáskutató és Fejlesztő Intézet, Budapest, 2015.

${ }^{10}$ Lénárd G. Biológia a gimnáziumok számára 11. Oktatáskutató és Fejlesztő Intézet, Budapest, 2015.

${ }^{11}$ Lénárd G. Biológia a gimnáziumok számára 12. Oktatáskutató és Fejlesztőlntézet, Budapest, 2015.

${ }^{12}$ Mándics D, Molnár K. Biológia-egészségtan tankönyv 10. Oktatáskutató és Fejlesztő Intézet, Budapest, 2015.

${ }^{13}$ Mándics D, Molnár K. Biológia-egészségtan tankönyv 11. Oktatáskutató és Fejlesztő Intézet, Budapest, 2015.

${ }^{14}$ Mándics D, Molnár K. Biológia-egészségtan tankönyv 12. Oktatáskutató és Fejlesztő Intézet, Budapest, 2015.

${ }^{15}$ Gál B. Biológia 10. Mozaik Kiadó, Szeged, 2016.

${ }^{16}$ Gál B. Biológia 11. Mozaik Kiadó, Szeged, 2016.

${ }^{17}$ Gál B. Biológia 12. Mozaik Kiadó, Szeged, 2016.

${ }^{18}$ Szerényi G. Biológia érettségizóknek 1. Mozaik Kiadó, Szeged, 2010.

${ }^{19}$ Szerényi G. Biológia érettségizőknek 2. Mozaik Kiadó, Szeged, 2010.

${ }^{20}$ Oláh Zs. Biológia 9. évfolyam. Nemzeti Tankönyvkiadó, Budapest, 2008.

${ }^{21}$ Oláh Zs. Biológia 10. évfolyam. Nemzeti Tankönyvkiadó, Budapest, 2008.

22 Oláh Zs. Biológia 11. évfolyam. Nemzeti Tankönyvkiadó, Budapest, 2008.

${ }^{23}$ Zátonyi Sz. Biológia a gimnáziumok 11. évfolyama számára. Apáczai Kiadó, Budapest, 2011.

${ }^{24}$ Nemzeti Köznevelési Portál: portal.nkp.hu 